\title{
The Course of a Life: The High Impact of Undergraduate Research and Mentoring
}

\author{
Christopher J. Young \\ Indiana University Northwest
}

The trajectory of my life changed in the most mundane of ways. It was on the first day of classes during my junior year in college. While seated at a desk in a classroom in the Armory at the University of Illinois, I awaited eagerly for what would be my first upper-division history course: Professor Robert McColley's course on Early National America, which covered the period roughly from the 1780s to the 1820s. After introducing the class, the professor handed out a list of topics and assigned one of them to each of us. My topic was William Blount (1749-1800). Who was William Blount, I wondered. The assignment was to write a research paper that would be due at the end of the semester.

As a first-generation student, I had had a rough start to college, but by the end of my sophomore year I had hit my stride. My plan was to become a high school history teacher. Finally, I was able to take an upper-division history course! I was excited and ready to go. Little did I know that my plans would change in roughly sixteen weeks.

I delved into the topic of William Blount. He proved to be a fascinating character during the nascent period of our nation's history. The very newness of the experiment in republican government during the 1790s and the expanse of the American Republic made for nebulous boundaries, loyalties, and principles. Studying the enigma who was the Governor of the Territory South of the River Ohio and later the first senator from the newly created state of Tennessee brought me into the riveting political cultural milieu of the 1790s — a period that would demand my attention from this initial entry as an undergraduate until I was tenured as an associate professor. It beckons me still from time to time.

The hunt for information about William Blount energized me. I loved reading about him! Every time I came across a primary document that mentioned the man I tingled as if I was the first person to uncover

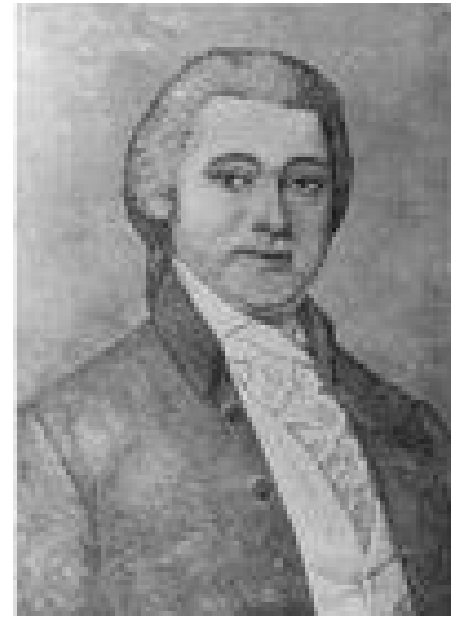

Figure 1. William Blount. this document. It was only the first time for me, but it felt like I was on to something, like I was the only one interested in this remarkable human being. How could people not be talking about this person all of the time? Why wasn't he taught in American history survey courses? Why is this the first time I am learning about him? I felt like a sleuth. I called his home in Knoxville, asked questions, requested material, and then felt like a kid on Christmas when his home sent me brochures and other material that I could use. The same for local historical societies in eastern Tennessee. 


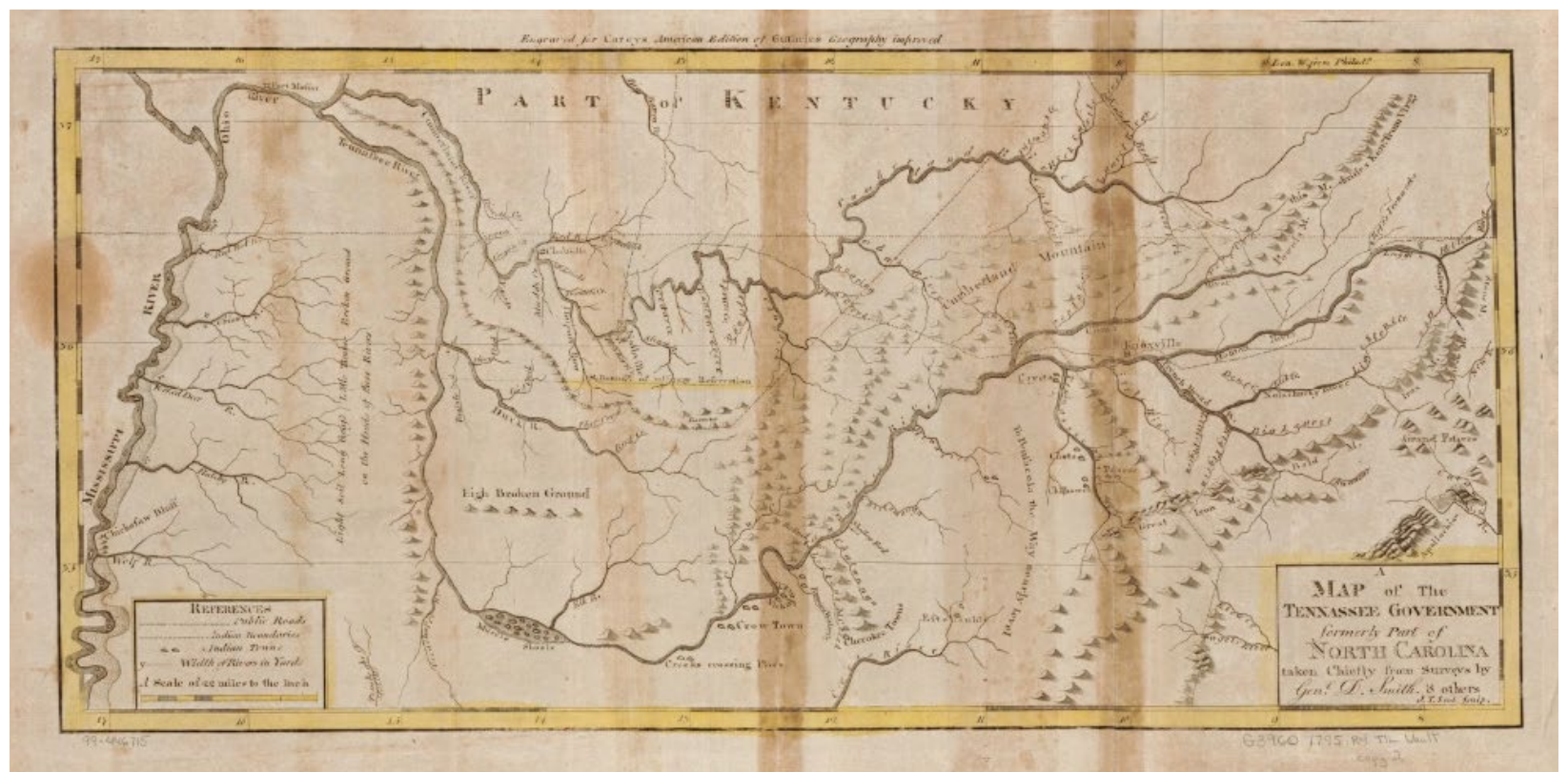

Figure 2. Map of Tennessee (1795).

Then came the writing. My Mom read and commented on so many drafts while I was home for Thanksgiving break that year, that she, too, became intrigued by "Mr. Blount" who we would talk about from time to time for years to come. Research tends to do that—make a subject yours for life.

Since it was my first research paper for my first upper division course, I was particularly anxious when I turned it in. When Professor McColley returned it, I read each comment before turning to the next page, resisting the urge to go straight to the last page. When I reached the final page, I was stunned when I saw A+! I couldn't believe it. I was thrilled. In his comments, Professor McColley commented on how thoroughly I did my research and noted that I had a "scholarly disposition." I loved doing the research and the writing. And now those comments from my professor. I was hooked! I felt like Abraham Lincoln did when he responded on April 29, 1860, to Lyman Trumbull's inquiries regarding his presidential ambitions, "The taste is in my mouth a little." As Lincoln's experience in the 1858 Illinois Senate race affected his future ambitions, so did this undergraduate research experience affect my own. Instead of moving on to other courses for a Social Science Second Education degree, I decided that I wanted to be a historian.

When it came time for me to do a senior honors thesis, I chose Professor McColley to be my advisor. It was a one-year project. We met weekly and I thoroughly enjoyed our discussions. My topic was American Indian policy during George Washington's presidency. At the end of a year of research and writing, the candidate had to defend the project before one's advisor and one other faculty member. When that day I arrived, I wore the best clothes I had and arrived on time. I was really nervous. When I finally sat down in Professor McColley's office, while he and another professor were settling in, I remember seeing pigeons outside his window and thought about how nervous I was and how calm they seemed. It was a timely and memorable distraction. After the defense, I was asked to leave the office and wait in the hallway while they discussed my performance. If I was nervous before, I was even more so now. I was to be judged. This moment would come back to me eight years later when I was once again asked to wait in the hall while a committee decided on my dissertation defense. Having been in this situation before helped cool my nerves at that time.

After I received my first appointment as an assistant professor at MacMurray College in central Illinois, I learned from my predecessor that he knew Professor McColley and that he had contacted 
him to ask about me during the search. The fact that I got the job made me assume my former mentor spoke well of me. If he had not, surely, I would not have been hired since I was to learn in time that the two men were longtime friends and colleagues. While at MacMurray College, I organized a symposium on slavery during the age of Stephen Douglas (Stephen Douglas had been a resident of Jacksonville, Illinois, at the beginning of his political career). I invited Professor McColley to give a presentation, and he agreed. It was rewarding to see my undergraduate mentor presenting at the symposium and then getting to know my wife when we went to diner afterward. Several years later when I was working on a project as an assistant professor at a different institution, I had to visit the archives at my alma mater. When I finished my research, I met Professor McColley and we went to lunch before he drove me to the Amtrak station. Relationships forged through conversation and mentorship during college remain into our professional lives.

My research projects as an undergraduate provided the opportunity to establish a close relationship with a faculty member at a large research institution. That relationship encouraged me to pursue and develop my intellectual interests, and to imagine myself in a profession that was different than what I had in mind before I stepped into Professor McColley's classroom. He was a teacherscholar who engaged in a high-impact practice. And that changed my life-and I like to think, through me, the lives of my students.

In my career as a faculty member, I have enjoyed encouraging students to take the deep dive into a research project. In that time, several of my students have published their work. One of them, while working on a topic closely related to his family's and Illinois's history with coal mining, reconciled his relationship with his father, which led to a hunting trip. Out of gratitude, he gave me half of the antler and a cooler of venison as a way of saying thank you. I was moved. I keep the antlers in my office as a reminder of the importance of relationships forged with our students and the students with us. Undergraduate research facilitates critical interpersonal developments and relationships that contribute to student success and enhanced life satisfaction.

Over the last eight years, I have organized the undergraduate research conference on our campus. My memory of the impact of undergraduate research and Professor McColley's mentorship on my own career-and life-trajectory reminds me that the annual conference isn't simply another campus event. I suspect that the faculty-regulars who participate had similar experiences as I did as an undergraduate and know in their hearts that the annual conference holds out the promise to be transformative in the lives of our students.

My research experience as an undergraduate and the relationship forged through it was a transformative experience. I learned that a topic will stay with you when you make it your own; words spoken and written to a student matter and can be life-changing; feelings experienced at one time can serve to inform similar feels at another time; and networks developed through undergraduate research open the doors to professional opportunities. Moreover, the experience gets at the essence of our humanity, the interconnectivity that binds us in a mysterious way.

After writing this essay, I decided to give Professor McColley a call. He is in his $87^{\text {th }}$ year and as sharp and articulate as ever. And just like our interactions when I was an undergraduate, I left our conversation with a list of three books that I need to read and that we'd discuss next time we talked. And like the first assignment I received from Professor McColley, I felt excited and energized about the new things I'd learn in the coming days and months. 


\section{References}

Reid, J. (1795) A map of Tennessee government, formerly part of North Carolina [S.l] [Map] Retrieved from the Library of Congress, https://www.loc.gov/item/99446175/.

William Blount, 1744-1800, bust portrait, facing right. nd. Retrieved from the Library of Congress, https://www.loc.gov/pictures/item/2005686050/. 